\title{
Existence, Enforcements and Practicability of the Legal Frameworks for the Protection of Women and Children's Rights in Nigeria
}

\author{
Zainab Abass Wasiu Babalola, PhD \\ Faculty of Law, Lead City University, Ibadan, Nigeria
}

\begin{abstract}
Nigeria has gained the unpopular recognition globally as a patriarchal society in which the inalienable rights of women are often subjected to ridicule, extensive abuse, neglect and violations. These abuses can also be traced to the non-protective nature of the Nigerian child among its citizenry. Cultural, religious and societal norms have arguably entrenched a historical imbalance in power relationships among men, women and children and have tilted the overall perceptions of the rights of women and children in Nigeria until recently. In Nigeria, it could be said that the abuse of the natural rights of a woman is a reflection of the non-challant attitude of the society to the recognition of the rights of the child. The rapid ascendancy of human rights in Nigeria, coupled with Nigeria's prominent role as a signatory to virtually all the core international human right treaties and instruments and the domestication of same in line with S.12 of its Constitution (1999 Constitution of the Federal Republic of Nigeria, as amended), raised expectations that women and children in Nigeria may begin to enjoy some measure of protection from archaic and anachronistic practices that subject them to wanton abuses. This paper examines the nature, scope and extent of human rights protection afforded to children and women under Nigerian domestic laws and under international laws. It reflects on Specific key issues as it relates to the protection and fulfillment of the rights of children and women in Nigeria. It further critic the existence and enforceability of such right laws while examining the practicability of the enforcements of the various provisions as contained in these legal frameworks already in existence for the protection of the woman and children in Nigeria. It is thus concluded that there exist circumstances that either facilitate or hinder the implementation of executed and domesticated treaties as it relates to women and children's rights, observed limitations to these rights were reported while agencies or bodies that could help to enforce these rights were recommended..
\end{abstract}

Keywords: Convention, Rights, Women, Child, Implementation, Administrative, Nigeria, Legal Framework DOI: $10.7176 / \mathrm{JLPG} / 91-16$

Publication date: November $30^{\text {th }} 2019$

\section{0 'Introduction}

The general frameworks within which human rights are protected in Nigeria are enshrined in the 1999 Constitution of the Federal Republic of Nigeria. Chapter IV contains an elaborate Bill of Rights. The right guaranteed include: the rights to life ${ }^{1}$, the rights to personal liberty ${ }^{2}$, the rights to fair hearing ${ }^{3}$ and the right to freedom of movement ${ }^{4}$ among others. Section 42 prohibits unjustifiable discrimination on basis of "ethnic group, place of origin, sex, religion or political opinion". As for penal infractions, Nigeria has two separate codes, one applying to Southern Nigeria (Criminal Code) and the other applicable to Northern Nigeria (Penal Code). These provide for offences against persons, including homicides, assaults and different kinds of sexual and gender specific violations such as rape . $^{5}$.

While history brings to light that the interrelationship between a man and a woman has always been in a state of flux and there has been a plethora of change in the position, rights, and status of women since the beginning of civilization. One relevant idea in understanding the structures of norms and values in the Nigeria society is the adherence to traditions and practices in dealing with women prior to the enactment of legislatures to support their causes. Although, the Child's Right Act was adopted in September $2003^{6}$, and seen as a right step in the right direction, very few states have passed the Child Rights Act into law. In 1967, the United Nations Member States adopted the Declaration on the Elimination of Discrimination against women ${ }^{7}$. By that declaration, the discrimination against women is an offence against human dignity and calls on States to "abolish existing laws, customs, regulations and practices that are discriminatory against women."It is against this backdrop that we will attempt to examine Human Rights as it relates to women. There are other instruments

\footnotetext{
*Akin Olawale Ogundayisi LL.B(Hons), LL.M, B.L, ACIArb; Legal Practitioner and Research

${ }^{1}$ See Section 33 of 1999 Constitution; See also Musa v. State (1993) 2 NWLR (Pt. 277) 500

${ }^{2}$ See Section 35 Ibid; See also Mohammed v. C.O.P. (1987) 4 NWLR (Pt. 65) 420

${ }^{3}$ Section 36, Awolowo v. Federal Minister of Internal Affairs (1962) LLR 177

${ }^{4}$ Section 41; Williams v. Majekodunmi (1962) 1 All NLR 413

${ }^{5}$ Section 357 Cap. 77 LFN 1990 on Definition of Rape and Section 358 on Punishment of Rape; Section 259 on Attempt to Rape.

${ }^{6} \mathrm{http}: / /$ www.unicef.org/WCRO_Nigeria_Factssheets. at. p.2 accessed August, 2013.

${ }^{7}$ Declaration on the Elimination of All Forms of Discrimination against Women (1967).
} 
which have been adopted by United Nations Member States in a bid to combat discrimination against women and also in order to protect the rights of women ${ }^{1}$. Remarkably, Nigeria just like many other nations has also ratified these declarations ${ }^{2}$.

\subsection{Definition of the Child}

The Child's Right Act 2003 passed into law in the Federal Capital Territory (Abuja), defines a child as person who has not attained the age of eighteen (18) years. However, according to Sec. 2 of the Children and Young Person Act, enacted in Eastern, Western and Northern regions, a "child" means a person under the age of fourteen years, while "young person" means a person who has attained the age of fourteen years and is under the age of seventeen years.

Furthermore, the Immigration Act stipulates that any person below 16 years is a minor, whereas the Matrimonial Causes Act 1970 puts the age of maturity at 21years ${ }^{3}$. The latter Act becomes irrelevant in practice, since the individual states their own age for marriage. As for penal responsibility, Section 50 of the Penal Code (North) states:

"No act is an offence which is done by a child under seven years of age; or by a child above seven years of age but under twelve years of age who has not attained sufficient maturity of understanding to judge the nature and consequence of such act."

These are only some examples of different ages enshrined in a multitude of legal texts and in customary law all over the country. These varieties in the minimum age limit pose a lot of problem in the process of interpretation. This can cause discrimination between children of same age in different parts of the country. It important for the government to review this aspect with a view to making a particular age workable for the purpose of implementing the Child Rights Act.

\subsection{Child Rights Act and the Domestication of the Convention on the Rights of the Child}

Generally, the convention on the Rights of the Child enjoins that:

Member states shall undertake to disseminate the conventions principles and take all appropriate legislative, administrative and other measures for the implementation of the rights recognized in the present convention ${ }^{4}$.

Against this background, a draft Child Rights Bill aimed at principally enacting into law in Nigeria the principles enshrined in the convention on the rights of the child and all charter on the rights and welfare of the child was prepared in the early ' $90 \mathrm{~s}$. But it is only after about ten years with several Heads of Government and geared debates by the parliamentarians that the Bill was eventually passed into law by the National Assembly in July 2003. It was assented to by the president of the Federal Republic of Nigeria, Chief Olusegun Obasanjo in September 2003, and promulgated as the Childs Rights Act $2003^{5}$.

In 1996, Nigeria submitted its first report on the implementation of the Child Rights Convention to the United Nation Committee on the rights of the child. One of the major recommendations made by the committee was to finally ensure the domestication of the Child Rights Convention, as this is necessary for its full implementation under Nigeria law ${ }^{6}$. A first bill on children's rights had already been discussed in 1993, but could not be passed into law by the military government, because of opposition from religious groups and traditionalists. A special committee was subsequently set up to "harmonize the children's bill with Nigerian religious and customary beliefs ${ }^{7}$. The Bill, providing for the rights and the responsibilities of children in Nigeria, as well as for a renewed system of juvenile justice administration, was rejected by the parliament in October

\footnotetext{
${ }^{1}$ African Charter on Human and People's Rights 1983 \& its Protocol which entered into force in January 2004, International Covenant on Civil and Political Rights 1966, UN Convention against Torture and other forms of Cruel, Inhuman or Degrading treatment or Punishment (CAT) 1984 \& Optional Protocol to the CAT, Universal Declaration of Human Rights, 1945. other instruments on international law concerning women are: Universal Declaration of Human Rights (1948), Convention on the political Rights of Women (1952), International Covenant on Civil and Political Rights (1966), International Covenant on Economic, Social and Cultural Rights (1966), Convention on the Elimination of All Forms of Discrimination against Women (1979) Optional and Protocol to the Convention on the Elimination of All forms of Discrimination against Women (1999), Declaration on the Elimination of Violence against Women (1993)

${ }^{2}$ Ratified international human rights Instruments in Nigeria: International Covenant on Civil and Political Rights (ICCPR) 29 July, 1993 , International Covenant on Economic, Social and Cultural Rights (ICESCR) 29 July, 1993, Optional Protocol on ICCPR concerning individual petition, Convention against Torture and other Cruel, Inhuman or Degrading Treatment or Punishment (CAT) 28 June, 2001, International Convention on the Elimination of all Forms of Racial Discrimination (CERD) 16 October, 1967, Convention on the Elimination of All Forms of Discrimination Against Women (CEDAW) 23rd April, 1984, Optional Protocol on the Elimination of all Forms of Discrimination Against Women (22nd November, 2004), Convention on the Rights of the Child (CRC) 19th April, 1991.

${ }^{3}$ But it allows person below this age to be married with the consent of the parents.

${ }^{4} \mathrm{http} / /$ www.unice.org/wcaro/WCRAO Nigeria Factsheets at p.2 accessed August, 2013.

${ }^{5} \mathrm{Ibid}$

6 CRC, Concluding Observation of the Committee on the Rights of the Child, CRC/c/15/Add.61 30/10/96; See also http://www.unhchr.ch/tbs/doc.nsf/(symbol)CRC.c.15Add61En?OpenDocument Accessed July 2013; See also Section 121999 Constitution on requirement for domestication of foreign articles and conventions.

${ }^{7}$ http://www.irinews.org/print.asp?ReportJD=30878, accessed August, 2013.
} 
2002- again on grounds of its contents being contrary to Islamic values, traditions and culture. The main objections targeted a provision setting 18 years as the minimum age for marriage. This was said to be compatible with religious and cultural traditions in various parts of the country, where girls are given in marriage at a younger age ${ }^{1}$. Many national and international Non-Governmental Organizations, as well as other sectors of the civil society in Nigeria, criticized this decision and forced the legislators to reconsider its decision to oppose to the Child's Right Bill.

It must be noted here that the provisions of the Act supercede all other legislations that have a bearing on the rights of the child ${ }^{2}$. Having been enacted at the national level, the states are expected to formally adopt and adapt the Act for domestication as state laws. This is because issues of child rights protection are on the residual list of the Nigeria constitution, giving states exclusives responsibilities and jurisdiction to make laws relevant to their specific situations. State laws inimical to the rights of the child are also to be amended to conform to the Act and the Child Rights Convention. The Nigerian government enacted the Child Rights Act and the various States of the Federation are required to domesticate the laws. Remarkably, Most states have domesticated this law thereby offering better protection to young girls, while some are yet to do $\mathrm{so}^{3}$. We hope that in the no distant future all states in the federation will domesticate this law.

Basic Provisions of the Child Rights Act

The Act recognizes the freedom of the girl child from discrimination on the grounds of belonging to a particular community or ethnic group, place of origin, sex, religion the deprivation or political opinion; and it is stated categorically that the dignity of the child shall be respected at all times. This provision is a corroboration of both constitutional provisions and International Conventions. It also guarantees the right of Nigerian child to rest, leisure and enjoyment of the best attainable state of physical, mental and spiritual health. The role of government in achieving this objective is imperative. The federal, state and local government is expected to ensure that there is a reduction in infant mortality rate provides medical and health care, adequate nutrition and safe drinking water, hygienic and sanitized environments. The federal government is enjoined by the Act to mobilize local and community in the development of primary health and care for children.

There is also a provision for the less privileged as well as those mentally, physically challenged under the Act. Street children are also protected in a manner that would enable them achieve their fullest, possible social integration, and moral development. The law also anticipates the interest of those who would probably be responsible for the care of the set of children that are orphans, abandoned or violated. Thus, expectant and nursing mothers shall be catered for. Every parent or guardian having legal, mental or emotional injury abuse or neglect, maltreatment, torture, inhuman, or degrading punishment, attacks on his/her honour or reputation.

The girl child is not left out as she also has her right as a child. The Child Rights Act of Nigeria, prohibits child marriage, and sets the age of consent as 18 years. ${ }^{4}$ The act also prohibits betrothal of a child. Any marriage of such nature is null and void and of no effect. The act makes it an offense to betroth a child under the statutory age of 18, the offender is liable upon conviction to a fine of N500,000 or to an imprisonment term of 5 years or both such fine and imprisonment. The intention of the law makers is to protect young girls and make it compulsory for care givers to abide by the provisions of this act.

In essence, the Act took cognizance of every person and individual concerned on the care and concern of children. Its basic provision could be said to follow fundamental human rights contained in Cap. IV of 1999 Constitution with specific focus on the children. It is important to note that there are other areas and issues covered by the Act such as the responsibility of a child, parental responsibility, child justice and some other salient issues. The Act could therefore be described as an innovative and commendable one.

It is worthy to mention here that the government has in addition to the Child Rights Act, ratified other treatises which have a significant bearing on the Act. The International Treatise and Protocols on Women and Children ratified by the government include:

- International Labour Convention 182 on Minimum Age;

- International Labour Convention 138 on Elimination of the Worse Forms of Child Labour;

- Optional Protocol to the Convention on Elimination of All Discrimination Against Women;

- Optional Protocol on the Involvement of Children in Armed Conflicts;

- Optional Protocol on the Sale of Children, Child Prostitution and Child Pornography;

- Convention Against Torture and other Cruel, Inhuman and Degrading Treatment or Punishment;

- Convention Against Trans-national Organized Crime; and

\footnotetext{
${ }^{1}$ Ibid

${ }^{2}$ See for example "Trafficking in Persons (prohibitions) Law Enforcement ad Administration Act which was passed into law on $14^{\text {th }}$ July 2003.

${ }^{3}$ A total of 23 states in Nigeria have endorsed the legal protection of children from all forms of violence, through the domestication of the national, https://www.today.ng/news/nigeria/124161/23-states-pass-child-rights-nigeria-unicef accessed on 15/5/2017. The Act has no effect in most Northern states as these states are yet to domesticate the Act.

${ }^{4}$ Section 21 of the Child Rights Act 2003
} 
- $\quad$ Protocol to Prevent, Suppress and Punish Trafficking in Persons, especially Women and Children.

However, these and other international documents have not been able to solve the problem of child abuse in Nigeria. In the words of A.A. Idowu:

"The African charter which consists of 48 Articles has clearly expressed the commitment of African nations towards positive steps at combating all forms of child trafficking in the continent. Notwithstanding these laudable aspirations of regional and international bodies towards the rights of the child, children in many African nations, particularly in Nigeria are still being trafficked on daily basis for different forms of exploitative labour ${ }^{l}$."

It is my humble submission that the Act beg for quick amendment so as so make it useful for the purpose it was made.

\subsection{Rights of Women}

The most basic right every human being is entitled to is the right to life, liberty and security of person. Every woman has the right to be alive and should not in any case be deprived of that right either through abusive conducts of their partners, in-laws or by any other unlawful means. Every woman has the right of dignity of her person; this fundamental right is provided for under our Nigerian constitution. ${ }^{2}$ In some states in Nigeria women are often subjected to barbaric widowhood tradition where they are forced to drink the bath water of their husbands' corpses especially when they die under mysterious circumstances, forced to sleep with their husbands' corpses on the same beds during the night of the wake-keep and afterwards swear before a village shrine to prove their innocence or otherwise ${ }^{3}$. This is clear violation of their right to dignity of their person.

In furtherance to this provision of our constitution, when conducting bodily search one women by the police it should be done by a female police officer having regard to decency while conducting searches. ${ }^{4}$ Every woman has the right to Freedom from slavery and torture ${ }^{56}$. Nobody has the right to turn a woman to slave or inflict pain; emotional, physical or psychologically. Your rights are protected by Law. No one shall be subjected to torture or to cruel, inhuman or degrading treatment or punishment. Torture is provided for under the UN Convention against Torture and other forms of Cruel, Inhuman or Degrading treatment or Punishment (CAT) 1984 \& Optional Protocol to the CAT. This convention protects women from being tortured. This protection applies to all women regardless of whether the person is serving a prison sentence or not.

The Convention on the Elimination of all Forms of Discrimination against Women (CEDAW) is one of the International Conventions protecting the rights of Women. The Nigerian has also government ratified this convention. ${ }^{7}$ This convention recognizes the rights of Women all over the world to be treated equally and fairly and not to suffer any disadvantage because of their gender. Article 1 of the Convention defines discrimination against women as "...any distinction, exclusion or restriction made on the basis of sex which has the effect or purpose of impairing or nullifying the recognition, enjoyment or exercise by women, irrespective of their marital status, on a basis of equality of men and women, of human rights and fundamental freedoms in the political, economic, social, cultural, civil or any other field." 8 The same Article I further define discrimination against women as "Anything that can bring about unequal treatment between men and women while carrying out their livelihood". This article groups married and unmarried women together. Article 13 stipulates in part that women have the right to obtain family benefits, while Article 15 states inter alia, that women have equal rights with men in matters of law related to business contracts. Under Article 16, women are empowered to own and give away their property.

By ratifying this convention, Nigerian government undertook an international commitment to eliminate all forms of discrimination against women. There have been attempts from various quarters to eliminate discrimination against women. Our courts have declared certain customs repugnant to natural, justice equity and good conscience for being discriminatory against women especially customs denying women the right to inherit their fathers property. ${ }^{9}$ This form of judicial activism has helped to promote the cause of women. Our

\footnotetext{
${ }^{1}$ A. A. Idowu, "Child Trafficking In Africa: The Nigeria Experience In Legal Thoughts", Ondo State Law Journal Vol.1 No.1 2004 Published by the Ondo State Ministry of Justice, Akure.

2 Section 34, 1999 Constitution of the Federal Republic of Nigeria (as amended).

${ }^{3}$ Although due too advocacy and rise of organizations against this, this practices have been eradicated in some states in Nigeria, however, it still exist in most societies in South-south, South West and South Eastern parts.

${ }^{4}$ Administration of Criminal Justice Act 2015, section 9(3), unless the urgency of the situation makes it impossible for the search to be conducted by the same sex.

${ }^{5}$ Section 34 of the 1999 Constitution. The only exception applicable to forced or compulsory slavery (labour) is provided in Section 34(2) of the Constitution.Nigeria has ratified but has not domesticated the Convention against Torture which is an international human rights treaty, under the review of the United Nations, that aims to prevent torture and other acts of cruel, inhuman, or degrading treatment or punishment around the world
}

${ }^{7}$ It was ratified on $13^{\text {th }}$ June 1985 but domesticated 2004.

${ }^{8} \mathrm{http}$ ://www.un.org/womenwatch/daw/cedaw/, Last assessed 21/5/2019

${ }^{9}$ Mojekwu v. Ejikeme(2000) 5 NWLR pt. 657, p. 402 
constitution has also provided that every person shall have the right to acquire property in Nigeria irrespective of the person's sex. ${ }^{1}$ This particular provision confers property rights to women and ensures that women are not denied such right merely on the basis of gender. .

Women have right against sexual violence ${ }^{2}$. Sexual violence takes the form of rape, gender discrimination, ethnicity or social status, violence in the home, sexual assault, female genital mutilation, speaking to women in a sexually impolite manner to mention but a few. Even female prison inmates are being violated sexually by being coerced into providing sex for favours such as extra food or psychological care available to inmates. Sexual violence is a violation of a woman's right to physical integrity, liberty and right to life itself.

The type of marriage contracted by a woman determines her inheritance rights over her husband's property upon his demise. Where the woman is married under the Matrimonial Causes Act, otherwise, generally referred to as Marriage under the Act, her inheritance right will be governed by the provision of the Administration of Estates Law of the relevant State of the Federation, where the couple were predominantly domiciled in the preceding years before the death of the husband. One very good feature of Marriage under the Act is that it upholds the tenets of monogamy, in the sense that, it is the marriage between one man and one woman to the exclusion of every other person. A woman married under the Act, has better protection under the law than a woman married under the customary law usually called traditional marriage. The woman married under the act can seek the protection of the court when subjected to any form of discriminatory treatment that tampers with her inheritance right. More so, it protects a woman's marriage; when she is unable to conceive a male child, she won't be thrown out of the marriage and neither can the husband marry a second wife as it will amounts to bigamy ${ }^{3}$.

A woman married under the native law and custom on the other hand is subject to the customs of her husband's locality in determining matters of inheritance of her deceased husband's estate and has no rights of inheritance over their deceased husband's estates. ${ }^{4}$ The only exception to the rule is the situation where the deceased husband leaves a Will. In this case, once the Will is valid, just like under English law, nobody can change its position or stop the woman from exercising her right of inheritance as provided for in the Will. The intent of the testator of the will must be followed strictly except in relation to family property in which case no one can bequeath such except the whole family in accordance with customary law and tradition.

More so, by virtue of married Women property Act of 1882, married women have the capacity of holding any type of property. The Act is still applicable in Nigeria today. As a woman you have the right to own your own things or share them with anyone of your choice, nobody has the right to take your things without a good reason or your permission.

The above positions were the law in Nigeria until through judicial activism and erudite decisions of our judges, ${ }^{5}$ as well as various laws in our country, the rights of women and girls to inherit either their father's or husband's estates is now well established. The Supreme Court of Nigeria, espoused the provisions of section 42 of the Constitution in the cases of Mojekwu v. Ejikeme, Mojekwu v. Mojekwu, declared null and void any customary law that tends to preclude a widow from inheriting from the estate of the late husband. Similar sentiments were expressed by the Supreme Court in the case of Ukeje v Ukeje [2014] 11 NWLR (PT.1418) 384 regarding the inheritance rights of the girl child and disavowing any customary law, which consigns the right of inheritance only to male children. Such custom is contrary to public policy and incompatible with the constitution of Nigeria.

Bodies Responsible for Protecting the Rights of Women in Nigeria

There are various National Bodies and Non-Governmental Organizations protecting and enforcing the rights of women, they include;

i. National Human Right Commission: This body handles human rights violations and have offices located in various parts of the country. All necessary information about this organization can be seen in their website. ${ }^{6}$ Their zonal office in the South West is at No 13A Ladipo Bataye Street .GRA, Ikeja, Lagos State.

ii. The Office of the Public Defender is also located in every state of the federation; they offer probono

\footnotetext{
${ }^{1}$ Constitution of the Federal Republic of Nigeria, Section 43.

${ }^{2}$ In the Northern states the rights of women are not recognized. The law also creates room for this violation; Section 55 of the penal code creates a fertile ground for violence against women. The section provides that "Nothing is an offence which dose not amount to infliction of grievous hurt upon any person which is done by a husband for the purpose of correcting his wife, such husband or wife being subject to native law or custom in which such correction is recognized as lawful".

${ }^{3}$ Various national Laws made it a criminal offence punishable with various jail terms; Lagos State has abolished the Law on Bigamy. Cultural and religious tenets in Nigeria have made this law inefficient.

${ }^{4}$ This is different in most Western states where female daughters are recognized, valued and given inheritance in their husband and fathers' house. Many a times a female is the eldest in such homes she takes the largest portion overriding the sons. In most part eastern states reverse if the case. An exception is Onitsha where women inherent properties.

${ }^{5}$ Mojekwu v. Ejikeme, Supra

${ }^{6}$ www.nigeriarights.gov.ng
} 
(free) services to indigent members of the public and help them to enforce their rights in the law courts. Information on how they can be contacted is on their website. ${ }^{1}$ The Ministry of Women Affairs promotes the cause of women; it has offices in all the states in the federation.

We also have private NGOs that are equally promoting the enforcement of the rights of women by offering legal services, and consultations in settling family disputes.

\subsection{A Critique of the Child's Right Act}

Notwithstanding the above sumptuous provisions, the Act has so many defaults which are inherent in it. Many scholars and international organizations have decried its implementation method since it has been passed. Thus, barely sixteen (16) years after it has been passed into law, the Act seems inefficient and ineffective in the face of recent child abuse reports in Nigeria. The second part of this article is an extensive analysis of the critique of the Act.

Nigeria operates a federal system of government, in which each of the 36 states of the federation is autonomous and equal to the others. Each states has its legislative system an as stated by the constitution. Until the Child's Right Act is enacted into law in each of these legislative systems, it is not binding on the states. Hence, no court can prosecute violations of the Child Right Act in states that have not enacted it. The rights of the Nigerian child are still at the mercy of the legislators. Several arguments have been employed by the states that have refused to sign the Child's Right Act, and all seem to allude to the diversity of cultures and of religion. Experience has shown, however, that the practice of giving out children in marriage at early states of their life without formal education or trade is predominant among the grassroots people especially the illiterates and may be less prevalent amongst the rich and educated citizens.

Additionally, there had been various debates on whether the Islamic religion is against 18 years as the marriageable age or not. Both the arguments for and against have been severally justified with different interpretation of the Koran ${ }^{2}$. This is only a typical example, but it refers the facts that there is always a difference between when the problem is really due to culturally relativity or political manipulations. Even when we may have reasons to think that these cultural and religious beliefs are rooted in the history of the people, we cannot neglect the fact that culture and religion, as well as history, are dynamic and change with evolving phenomena.

As a matter of fact, it is impossible to have rights protected without a special force, which can justify the claims to such rights as Donnelly identified ${ }^{3}$. The legislative problems with the Child Rights Act in Nigeria simply signify that the rights of the child cannot be claimed in states that have not incorporated such acts. However, Nigeria cannot be exampled from her legal obligation to protect child rights, having signed and ratified the Child's Right Convention. Nigeria has not only failed to ratify the Child Rights Convention, but has also failed in giving any seriousness to her commitments to the spirit and letters of the Convention. The failures of Nigerian government to legislate the Child's Right Convention effectively and curb the violation of child rights can be traced to a failure to educate her citizens on human rights generally and child rights specifically. Nigeria's signature of the United Nations Declaration of Human Rights puts an obligation on her to disseminate, display, and incorporate human rights in institutions of learning, yet this has not been accomplished.

\subsection{Conclusion and Recommendations}

Knowing our rights is one thing and knowing how to enforce it is another. It is said that wisdom is profitable to direct. Nigeria is still advancing and despite its ratification of virtually all International Instruments on protection and promotion of gender rights, some of these treaties have not been domesticated as national laws and therefore cannot be employed in defence of cases involving their violations before our local courts. Thus, it remains ordinary document in the nation's legal framework and has only a persuasive effect.

The Child Rights Act 2003 was not just a 'formal' document passed with a view to add to existing ones. The domestication of the Act in some states, also emphasize its importance even at the local level. Thus, there is the urgent need for a quick and effective implementation, awareness and conscientisation by all and sundry. According to Monrad Paulsen:

"No law can be better than its implementation, and can be no better than resources permit"."

Thus, government, non-governmental organizations, parents and individual should be ready to support the full realization of the provision of the Act in its entirety. Government need to provide adequate resources and opportunity. Non-Governmental Organizations should show support with their own campaign, while parents and individual should co-operate with the government, by fulfilling their own responsibilities as provided.

There is an urgent need to revive the traditional values and standards of Nigerian societies. The family

\footnotetext{
${ }^{1}$ www.Opdlagostate.gov.org

${ }^{2}$ Eze Anaba, 2003, "Why The Child Rights Bill Must Be Passed Into Law", in Vanguard Newspapers, Nigeria, Friday 16 May 2003 , p. 26

3 Jack Donnelly: 1989, "Universal Human Rights in Theory and In Practice", Ithaca and London; Cornel University Press, p.9

${ }^{4}$ See "The Law and Abused Children" in the Buttered Child, R Helfer and C. Kempe eds. (University of Chicago Press, (1974) quoted in the Ideologies of Children's Rights, M. Freeman and P. Vierman eds. (Martins Nig. Roff Publishers, 1992 at p.41.
} 
institution need to be strategically helped to take its leafing role in socialization process of its members ${ }^{1}$. These are necessary steps towards ensuring an effective implementation of the Child's Right Act. As we can see, the Child's Right Act 2003 is a very ambitious legislation which seeks to cover practically all issues of civil and criminal law relating to the child ${ }^{2}$. This is highly commendable because it is an attempt to adopt a world view of the subject matter. Needless to say, that its provisions have been borrowed from the United Nations Conventions on the rights of the child 1989 and Organization of African Unity Charter on the rights and Welfare of the Child 1990 .

Generally, human rights education will enable us to build a culture of universality of human rights, and it will also provide the legal atmosphere that Nigeria needs to promote, protect and enforce women and child rights. This burden of creating awareness now lies on human rights conscious individual in various capacities, be it academics, press, or organizations such as Non-governmental organization as well as the United Nations agencies in Nigeria.

There is a need for gender parity in allocation of resources. This will go a long way to empower women who in turn are better placed to face the challenges of the 21 st century. When you empower a woman you have empowered a nation. An empowered nation can compete globally and as such due regard will be given to the stance of such nation on any issue globally.

\footnotetext{
${ }^{1}$ International Journal, "Law and Contemporary Studies", Development Universal Consortia, Vol.1 No.1 \&2 2006 ISSN 1597-7560 pp. 199 217

${ }^{2}$ Journal of Ebonyi State University, Faculty of Law, Vol.1 No.1 October 2005, “Comments on Child's Rights Act 2003” at pp.159-169
} 